\title{
Notas pedagógicas para a dança: considerações sobre a formação e a atuação do intérprete de dança
}

Pedagogical notes for dance: considerations on the training and practice of the dance performer

Rafael Henrique Viana Sertori ${ }^{1}$ 


\section{Resumo}

A escrita desse artigo tem por objetivo apresentar algumas discussões em torno da formação e da atuação do intérprete de dança, considerando a multiplicidade de contextos artísticos e pedagógicos nos quais a dança se estrutura. Além disso, defende-se o uso do termo intérprete de dança, na tentativa de descrever e refletir sobre suas especificidades de criação e atuação nessa linguagem artística. $O$ artigo ainda apresenta trechos de entrevistas realizadas com duas artistas-pedagogas que atuam na cidade de São Paulo, a fim de contribuir com a discussão sobre o intérprete na atualidade.

Palavras-chave: Intérprete de dança; dança contemporânea; pedagogia da dança; artista-pedagogo

\section{Abstract}

This article has the objective to introduce some discussions on the training and practice of the dance performer, considering the multiplicity of artistic and pedagogical contexts in which dance is structured. Furthermore, the use of the term dance performer is advocated, in order to describe and reflect on his/her creation and practice's particularities in this artistic language. The article also presents excerpts from interviews with two artists-educators of São Paulo city, in order to contribute to the discussion on the dance performer nowadays.

Keywords: Dance performer; contemporary dance; dance pedagogy; artist-educator

E-ISSN: 2358.6958

1 Doutorando do Programa de Pós-Graduação Interunidades em Estética e História da Arte (PGEHA-MAC/USP). Universidade de São Paulo (USP). Ator, dançarino e artista-pesquisador. rafael.sertori@gmail.com 


\section{Alguma vida ao corpo do Intérprete ${ }^{2}$}

O que é ou o que significa ser intérprete de dança? De um modo geral, o termo intérprete pode ser entendido como aquele sujeito que traduz algo a alguém, que realiza uma mediação entre duas ou mais pessoas ou, ainda, como aquele que revela algo que está oculto. No contexto das artes do espetáculo, ao considerarmos o intérprete de dança como um artista que leva tanto para a cena, quanto para os processos de criação, tudo aquilo que apreende do seu contexto sociocultural e de sua vida no mundo, temos um vislumbre do que ele pode vir a ser (se assim o quiser), a partir das palavras de Jacques Rancière (2009, p. 36):

O artista é aquele que viaja nos labirintos ou nos subsolos do mundo social. [...]. Devolve aos detalhes insignificantes da prosa do mundo sua dupla potência poética e significante. Na topografia de um lugar ou na fisionomia de uma fachada, na forma ou no desgaste de uma vestimenta, no caos de uma exposição de mercadorias ou de detritos, ele reconhece os elementos de uma mitologia. E, nas figuras dessa mitologia, ele dá a conhecer a história verdadeira de uma sociedade, de um tempo, de uma coletividade; faz pressentir o destino de um indivíduo ou de um povo.

Considerando as palavras de Rancière, é possível identificarmos aspectos que são de natureza social, poética, política e expressiva no trabalho e na atuação do intérprete. Ao dançar e escolher interagir com o mundo por meio de seus movimentos corporais, sua função passa a ser, entre outras coisas, a de interpretar, digamos assim, todos os estímulos que lhe chegam e todo o material que encontra ao se lançar nos "labirintos ou nos subsolos" de seu mundo social, garantindo-lhes certa materialidade cênica e poética. Contudo, investigar a figura e a atuação do intérprete de dança na contemporaneidade traz consigo uma multiplicidade de questões, abrangendo desde os meandros de sua formação enquanto artista (envolvendo elementos da técnica, da preparação corporal, do estudo, do treinamento, das estratégias e dos procedimentos de pesquisa de movimento e de criação em dança), até questões referentes à sua formação e desenvolvimento enquanto indivíduo e sujeito social; questões, portanto, ético-estéticas. Considerando-se a complexidade de tais assuntos, podem ser encontradas ferramentas de investigação advindas das mais diversas áreas do conhecimento. Traçando-se um paralelo entre as pesquisas realizadas sobre o intérprete de dança com os estudos "atorais", desenvolvidos pela professora e pesquisadora Lúcia Romano, é possível constatarmos que:

Em termos metodológicos, a análise dos discursos plurais sobre a prática do ator e da atriz (portanto, de intérpretes) com vistas à elaboração de um recorte da teoria atoral exigirá uma diversidade de ferramentas, cujo emprego visa atingir três objetivos: permitir a historicização; oferecer destaque aos elementos do processo criativo; e conduzir à reformulação de juízos críticos. (Romano, 2013, p. 05. Grifo do autor)

\footnotetext{
2 Parte desse tópico encontra-se publicada no livro Trajetórias em construção: escritos cênicos dos pesquisadores do LAPETT (Curitiba: Editora Prismas, 2016). No entanto, neste artigo o autor optou por realizar algumas revisões, alterando partes e incluindo outras ainda não publicadas.
} 
Ao prosseguir com a tentativa de trazer destaque aos elementos que constituem o intérprete de dança, é possível encontrarmos semelhanças também com o trabalho e a atuação de atores. Nesse sentido, o professor e pesquisador Cassiano Sydow Quilici traz à tona algumas palavras de Antonin Artaud ${ }^{3}$, apresentadas em sua obra Antonin Artaud: teatro e ritual (São Paulo: Annablume; Fapesp, 2004), por meio das quais podemos compreender o intérprete como o sujeito que, através de seu trabalho, consegue "dissolver a carcaça de indivíduo para abrir-se aos outros seres, para poder respirar com a vida do mundo" (Quilici, 2004, p. 203). Para o pesquisador Cassiano Quilici (idem): "Artaud entendia que outros povos e outras épocas conheceram mais de perto essa experiência, compreendendo o ser humano como ponte, elemento de ligação entre a terra e o céu, trânsito entre a forma e o não-manifesto".

Porém, na tentativa de mapear e trazer um pouco mais de clareza, especificamente, para a figura do intérprete de dança, considerarei algumas proposições formuladas a partir da Dança Moderna alemã, uma vez que acredito ser nesse período que os intérpretes passaram a conquistar maior autonomia frente à criação em dança. Para um dos fundadores e pesquisadores da "nova dança" alemã, o bailarino, coreógrafo e pedagogo húngaro Rudolf von Laban (1879-1958), segundo as palavras de Eugenia Ropa (2014, p. 78):

O dançarino, em sua totalidade psicofísica, era colocado na origem e ao centro do processo dinâmico expressivo, e dele fazia descender os modos, os significados e as leis do movimento. Traduzia em manifestação rítmica exclusivamente os próprios impulsos e ritmos fisiológicos, emocionais e intelectuais; era criador, meio e norma da própria dança, expressão não mediada da harmonia de sua vida e instrumento de acorde sintônico com a harmonia da vida universal.

A partir dessa ideia de Laban descrita acima, é possível começarmos a compreender o sujeito que dança como um intérprete, primeiramente, de seus "próprios impulsos e ritmos fisiológicos, emocionais e intelectuais", proporcionando-lhes alguma materialidade poética por meio da expressão e realização de movimentos corporais. De acordo com Müller (apud Pereira, 2010, p. 28): “Laban pretendia exatamente redespertar os talentos emocionais e irracionais adormecidos das pessoas e, a partir desta experiência individual, que elas viessem a ter uma vivência através do movimento". Nesse contexto, onde a dança era encarada como "experiência do cosmos em forma de movimento", os intérpretes eram vistos como aqueles que:

[...] deveriam evidenciar somente sua capacidade pessoal de deixar-se penetrar pelo ritmo cósmico, elevar-se com ele e trazer consigo os espectadores. Assim, sua dança passa a ser um 'serviço sagrado' que deve ser executado com humildade, colocando à disposição, na relação entre humanidade e divindade, a própria alma e o próprio corpo. (Ropa, op. cit., p. 85)

Todas essas ideias e apontamentos sobre o sujeito que dança, desenvolvidos durante o período em que Laban atuou artisticamente, culminaram no surgimento de outras propostas poéticas presentes na Dança Moderna alemã, como a Ausdruckstanz (Dança de Expressão ou Dança Expressionista), cuja principal protagonista

3 Antonin Artaud (1896-1948) foi poeta, ator, escritor, dramaturgo, roteirista e diretor de teatro francês. 
foi a bailarina e coreógrafa alemã Mary Wigman (1886-1973), e o Tanztheater de Kurt Jooss (1901-1979). Para ambos, a importância de se desenvolver uma dança que viesse garantir aos seres humanos o domínio e a redescoberta de si, primeiramente, era crucial, sendo que esse objetivo deveria ter início no próprio processo de formação e preparação dos bailarinos. Com isso, acreditavam que poderiam contribuir com a constituição e com o desenvolvimento de saberes que formariam indivíduos mais conscientes do mundo em que viviam. Para Kurt Jooss, o importante era "formar bailarinos que desenvolvessem através de seu instrumento - o corpo - não a técnica pela técnica, mas sim ótimas possibilidades para trabalhar com precisão, sinceridade espiritual e humanidade" (Bartelt, apud Pereira, op. cit., p. 31). Já Mary Wigman (apud Bourcier, 1987, p. 299), em suas reflexões enquanto artista-pedagoga, dizia que:

Formar o dançarino é, portanto, torná-lo consciente dos impulsos obscuros que estão dentro dele. Nada de sistemas preestabelecidos, menos ainda adestramento corporal. É preciso se pôr à escuta de si mesmo, onde se pode ouvir a repercussão do eco do mundo.

Essas propostas contidas nas danças alemãs do início do século $\mathrm{XX}$, as quais nos sugerem encarar o intérprete como um sujeito autônomo, consciente, criador e propositor de suas próprias danças e de seus próprios modos de mover-se, ou como um sujeito cuja dança seria capaz de revelar e repercutir os ecos da humanidade e do mundo, influenciaram o pensamento de toda uma geração que produz e pratica o que, hoje, chamamos de dança contemporânea, seja por um processo de ressonância ou pela transmissão das técnicas ao longo da história. Se tomarmos como exemplo as reflexões elaboradas acerca do fazer artístico de intérpretes de dança, tendo como base as criações contemporâneas em dança, encontramos nas palavras da francesa Laurence Louppe, historiadora e crítica de dança, a seguinte afirmação: "ser bailarino é escolher o corpo e o movimento do corpo como campo de relação com o mundo, como instrumento de saber, de pensamento e de expressão" (Louppe, 2012, p. 69). Já para o importante pensador contemporâneo das relações entre dança e filosofia, o filósofo português José Gil (2013, p. 11):

O bailarino retoma o seu corpo no momento preciso em que perde o seu equilíbrio e se arrisca a cair no vazio. Luta, jogando tudo por tudo: está em jogo a sua vida, a sua liberdade de bailarino, a sua luz. Faz apelo ao movimento, que proporcionará claridade e estabilidade à sua extrema agitação interior. Por meio do movimento domará o movimento: com um gesto libertará a velocidade que arrebatará o seu corpo traçando uma forma de espaço. Uma forma de espaço-corpo efêmero, por cima do abismo.

Considerando então todas as proposições apresentadas até aqui, numa primeira tentativa de delinear teoricamente a figura do intérprete de dança, podemos observar que o intérprete é aquele que se desenvolve, interage e dialoga com o mundo por meio de movimentos criados a partir de impulsos e ritmos fisiológicos, emocionais, intelectuais, espirituais e universais, sentidos e experienciados em seu próprio corpo. Vive uma relação integral de idas e vindas com seu corpo, passando ora pelo estranhamento, ora pela aceitação dos fluxos energéticos e dos movimentos que o atravessam, de modo a superar tanto os desafios que lhe são apresentados durante a realização de 
seu trabalho, quanto para conhecer, agir, interferir, expressar-se e relacionar-se com o mundo, com tudo e com todos à sua volta, através de sua dança. Nesse processo de autoconstrução, conhecimento e reelaboração de si, o intérprete verá que é quase impossível não "dissolver a carcaça de indivíduo para abrir-se aos outros seres", pois, ao lançar-se na experiência do dançar, para além de sentir os movimentos de suas células, de seus fluidos, ossos, órgãos e músculos, percebe também o movimento de todo um universo contido em si; passa a "respirar com a vida do mundo". Nesse sentido, o corpo do intérprete já não é mais apenas o corpo de um indivíduo:

[...] mas um lugar, habitado por uma "multidão". Multidão de impulsos, sensações, excitações, pensamentos, num movimento veloz e perpétuo de aparição e dissolução. Um corpo-multidão, onde circulam uma miríade de experiências, impossíveis de serem completamente catalogadas e fixada. (Quilici, op. cit., p. 198)

Esse constante, intenso e duradouro processo de conhecimento e reelaboração ininterrupta de si, dos limites físicos e capacidades técnicas do próprio corpo, dos operadores e elementos que constituem a cena, da relação que se estabelece com a criação em dança e também com os espectadores (dentre vários outros aspectos), exige de qualquer intérprete de dança um tanto de coragem e muita disponibilidade para lançar-se no vazio. Nesse caminhar, o intérprete precisa dispor de certo rigor, disciplina, concentração e determinação, mas também de afeto, cuidado e paciência para encarar seu processo de desenvolvimento enquanto sujeito-intérprete, sobretudo no que diz respeito à elaboração da autonomia necessária para autoinvestigar-se e entender como pode se dar a estruturação poética desse "corpo-multidão". Essa autonomia também auxiliará o intérprete a relacionar-se criativamente com os enigmas e desafios que residem na imaginação dos coreógrafos, muitas vezes tendo que desconstruir e/ou aprofundar o entendimento que possui do próprio corpo, dos inúmeros elementos, estímulos e matérias-primas que constituem um processo de criação em dança, bem como das possíveis relações entre dança e sociedade.

Estar aberto para compreender ou, pelo menos, para tentar apreender um pouco mais da realidade e dos desejos do outro, para além de contribuir com o desenvolvimento de relações construtivas, saudáveis e edificantes, proporciona ao intérprete também a experiência de poder reinventar-se a cada novo processo de criação em dança. Essas relações tecidas com os movimentos e com a dança, muitas vezes, também trazem aos intérpretes um campo fértil, cheio de possibilidades para revisitarem suas ações no mundo e seus modos de interagir com o mundo, para reelaborarem seus processos de tomada de consciência sobre aquilo que dançam e, principalmente, para quê e para quem dançam. Contudo, aqui vale uma pergunta: por que defender o uso do termo intérprete de dança?

\section{Afinal, por que intérprete?}

Com a crescente produção em dança ocorrida nas últimas décadas, sobretudo nas grandes capitais, caracterizada pelos mais distintos modos de criação, hoje em dia se tornou frequente nos depararmos com várias formas de escrita para designarmos o sujeito que dança. Intérprete, dançarino, ator-dançarino, intérprete-dançari- 
no, intérprete-criador, criador-intérprete (entre outros): inúmeros termos que geram e propõem múltiplas interpretações e significados; várias expressões criadas no intuito de tentar representar e elucidar a atual multiplicidade dos modos de produção e criação artística, bem como as transformações políticas, poéticas e estéticas ocorridas no fazer e pensar a dança ao longo do tempo. No entanto, o que mais esses termos trazem consigo? Para onde nos levam quando empregados no cotidiano e nos estudos em dança? Ademais, no contexto das danças produzidas em nossa contemporaneidade, não é raro nos depararmos com indagações do tipo mas, e vocês, atuam só como intérpretes ou também como criadores? A princípio, essa questão, além de trazer consigo (conscientemente ou não) uma ideia que menospreza o trabalho, a atuação e a função do intérprete na (e para a) dança, também aponta certa limitação em relação aos possíveis modos de compreendermos a criação em dança, os quais se apresentam, atualmente, de várias maneiras. Logo, frente a essa pergunta, outra se faz absolutamente necessária: ao empregarem o termo criadores, falam sobre a criação de quê?

Num primeiro momento, podemos pensar que a criação da qual se fala, nesse sentido, está relacionada à coreografia que se materializa na cena ou no espaço cênico enquanto obra de dança. Essa coreografia, por sua vez, pode ser elaborada tanto a partir de uma sequência de movimentos organizados em partituras corporais, quanto da concepção e execução de um roteiro ou projeto coreográfico (não necessariamente realizado por meio de partituras ou estruturas corporais predeterminadas) ${ }^{4}$. Nesse sentido, Paulo Paixão (2003) nos esclarece que:

Coreografia na contemporaneidade pode ser entendida como a estrutura de conexões entre diferentes estados corporais que figuram em uma dança, e dela faz emergir seus nexos de sentidos. Ela é quem regula as relações entre os elementos de uma dança, portanto regula a média de informação veiculada atuando como uma gramática. [...] Coreografia pode ser entendida como escrita da dança na medida em que ela é quem permite que a dança seja descrita.

Atualmente, tendo em vista a grande recorrência de modos de produção artística sendo desenvolvidos em caráter colaborativo ${ }^{5}$, parece que se tornou difusa a importância de explicitar quem é o sujeito que cria essa "escrita da dança" que se vê em cena: se é o coreógrafo ou o próprio intérprete. Desse contexto da criação artística em caráter colaborativo, por exemplo, emergem os termos e as figuras do "intérprete-criador" e do "criador-intérprete" para evidenciarem a participação dos intérpretes na construção e criação de uma proposta coreográfica. Sob essa perspectiva, o termo "intérprete-criador" pode ser entendido como o intérprete que, a partir de seus próprios elementos criativos e de suas próprias ideias e propostas poéticas, dança e colabora com o coreógrafo na criação coreográfica, sempre que solicitado. Já o termo "criador-intérprete" abrange o intérprete que atua como o seu próprio core-

\footnotetext{
4 Considerações significativas que contribuem para a discussão em torno do conceito de coreografia podem ser encontradas no artigo 0 conceito de coreografia em transformação, de Juliana Moraes, disponível em: http://www.revistas.udesc.br/index.php/urdimento/article/view/1414573101342019362.

5 No Brasil, foi principalmente após as contribuições teóricas do encenador, professor e pesquisador Antônio Araújo que esse modo de criação passou a ser conhecido, adotado e difundido. Hoje em dia, o termo colaborativo é usado para designar os processos artísticos em que todos os sujeitos envolvidos, atuando em suas funções específicas, colaboram com a criação de uma obra artística.
} 
ógrafo, tanto elaborando quanto dançando suas próprias propostas coreográficas. Tais binômios começaram a surgir tanto na escrita, quanto na prática da dança, numa tentativa de evidenciarem, entre outras coisas, os incontáveis e distintos modos, presentes na contemporaneidade, de se fazer e pensar a criação artística. Consequentemente, tais modos trouxeram consigo uma série de discussões de natureza política, estética e artística, as quais abrangem, inclusive, a utilização escrita dos binômios citados no intuito de se garantir uma maior compreensão sobre os conhecimentos produzidos em relação à dança.

Nesse momento, vale dizer que o emprego desses termos também traz consigo a ampliação do entendimento sobre várias outras questões presentes na dança e em seus processos criativos, dentre as quais podemos citar: a autonomia criativa conquistada pelos intérpretes; a liberdade em estabelecer relações subjetivas com o movimento dançado ou com o material coreográfico; a eclosão de novas modalidades técnicas e de novos vocabulários de movimentos sendo empregados nos processos criativos; o desenvolvimento de novos procedimentos para a preparação corporal; a presença de profissionais na dança advindos de outras áreas e linguagens artísticas, entre outras. Por outro lado, ao empregarmos os binômios "intérprete-criador" e/ou "criador-intérprete" nos estudos sobre o fazer artístico em dança, a perspectiva de entendimento sobre a figura do intérprete que prevalece diz respeito, quase sempre, ao termo "criador". Por conseguinte, este termo pode nos direcionar a uma compreensão predominantemente relacionada à criação coreográfica. Dessa maneira, ao adotar apenas o termo "intérprete" neste artigo, o que proponho é que olhemos para o aspecto "criador" presente na figura do intérprete para além da criação coreográfica. O que mais o intérprete cria (ou pode criar) na dança e com a dança, sendo ele, acima de tudo, um artista da cena?

Assim, a escolha em aderir apenas ao termo "intérprete" nessa escrita estruturase com o objetivo de podermos investigar outros elementos inerentes à sua criação poética, bem como de sugerir outras perspectivas de entendimento sobre a criação em dança, podendo essa ser pensada e descrita, inclusive, pelos próprios sujeitos que dançam. Ou seja, ao adotarmos o termo intérprete na escrita da dança, deslocamos o interesse sobre a autoria da criação coreográfica para a busca pelo entendimento de como pode se dar a criação de relações possíveis de serem estabelecidas pelo sujeito que dança. O foco é direcionado para o humano, empenhado em reencontrar-se consigo mesmo e com o sentido próprio do seu trabalho: um trabalho relacional e experiencial. Sob essa perspectiva, podemos compreender a criação em dança não apenas como a estruturação de partituras corporais ou de propostas coreográficas, mas também enquanto criação de novas possibilidades de se interagir psicofísica e energeticamente com o corpo, com aquilo que se dança, com a produção do conhecimento nessa área, com determinado vocabulário coreográfico, com determinada técnica de dança, com a cena, com o espaço e com o ambiente cênico, com o espectador; enfim: com a dança enquanto expressão e proposição de uma outra gramática dos corpos em sociedade.

Além disso, as relações estabelecidas pelo intérprete com o coreógrafo, com seus parceiros de cena e com o espectador também se tornam material em potencial 
à sua criação. À medida que o intérprete se coloca disponível para estar no momento presente; à medida que se coloca à escuta daquilo que se passa entre um movimento e outro, entre o seu corpo e o corpo do outro, entre o seu mundo e o mundo do outro (por exemplo), certamente perceberá também a oportunidade de poder evidenciar e materializar em dança, em movimento e através do movimento, a dinâmica das relações subjetivas contidas no atravessamento dessas experiências consigo mesmo e com o outro. Nessa dinâmica das relações, o intérprete torna-se cocriador da dança que se materializa em um determinado espaço-tempo, realizando ativamente a consciência desse processo (movente) de si consigo mesmo, com seus parceiros de cena, com o coreógrafo e com o público. Se assim o quiser, o intérprete pode, portanto, também propor ou promover ao espectador uma experiência de dança. Ou seja, as oportunidades de se colocarem disponíveis para vivenciarem uma experiência de dança estão dadas, tanto para intérpretes, quanto para espectadores. Se o intérprete, ao ir para a cena, dá a ver todo esse processo de movimentos (energéticos, emocionais, intelectuais), internos e externos a seu corpo e, ainda, se ele se mantém consciente do que o seu corpo produz enquanto dança (ou enquanto linguagem poética), o espectador, por sua vez, tem a possibilidade de sentir esse processo em seu próprio corpo a partir dos movimentos gerados em si durante o momento em que frui a obra coreográfica; durante o tempo em que vê, materializados no espaçotempo efêmero de uma dança, os resultados do trabalho do intérprete. Logo, nesse momento, por meio da fruição, o espectador também pode tornar-se cocriador da dança que se evidencia na cena.

Em muitos casos, por mais que a autoria pela criação coreográfica ainda seja destinada ao coreógrafo, a responsabilidade pelo que foi (ou é) criado evidencia-se, no fazer artístico do intérprete, no exato momento em que ele se coloca em cena e se vê diante do público. Nesse momento, cabe ao intérprete assegurar, ao máximo, a realização do que foi elaborado durante o processo criativo, seja responsabilizandose por suas próprias escolhas criativas ou pelas escolhas de um coreógrafo. Quando se é intérprete de uma companhia ou de um coreógrafo, por exemplo, é recorrente o sentimento de que há que se colocar disponível para escutar muito mais o desejo do outro e a proposta do outro, deixando de lado sua própria criação e seus próprios desejos. Se isso ocorre, é importante ter vontade de apreender, ao máximo, as realidades e visões de mundo do outro, sabendo que tal apreensão também constitui a criação poética e artística de uma obra coreográfica. Logo, poderíamos sugerir que é neste momento que o intérprete tem a possibilidade de colocar em ação o seu aspecto "criador", uma vez que pode se valer do material proveniente dessa apreensão para poder criar, dançar e expressar em movimento o entendimento que consegue elaborar sobre o outro, bem como sobre o que o outro lhe apresenta enquanto proposta poética, materializando novas gramáticas corporais. Nesse exercício do intérprete, pode inclusive surgir a criação de algo não esperado ou não previsto de antemão, nem pelo coreógrafo, tampouco pelo intérprete; algo que é gerado pela própria relação poética estabelecida entre os dois durante um processo criativo. Ambos, quando são considerados como propositores de materiais, de elementos e movimentos que constituem uma criação em dança, tornam-se cocriadores dos operadores que 
constituem a cena contemporânea. Para além disso, intérpretes e coreógrafos tornam-se cocriadores, também, de novas perspectivas de entendimento sobre criação em dança; portanto, novas visões sobre a arte no mundo.

Com esse modo de atuar, por exemplo, o intérprete pode contribuir com a diminuição do espaço que pode existir entre seus próprios desejos e os desejos do outro durante uma criação artística. Ao estabelecer, de fato, essa relação construtiva com o universo criativo do outro, o intérprete cria a possibilidade de poder revelar e materializar, de múltiplas formas, a alteridade que circula nas artes cênicas. Além disso, também torna-se possível, ao intérprete, viver a experiência de transformar em dança e de colocar em movimento um pouco dos pensamentos, emoções e desejos que constituem o universo criativo, a realidade e o mundo do outro. Ou seja, tal desafio configura-se enquanto oportunidades para que o intérprete se aprofunde, cada vez mais, no desenvolvimento de suas habilidades de cocriador e propositor de uma dança (de um jeito de materializar uma dança), além de poder se aprofundar, também, no entendimento sobre as especificidades características ao seu próprio fazer artístico, sobretudo quando se está na cena. É claro que, para isso ser possível, o intérprete deve se identificar (minimamente) com esse modo específico de criação, caracterizado principalmente por uma relação de troca entre intérprete e coreógrafo.

Portanto, o emprego do termo intérprete pressupõe que sua contribuição e seu valor significativo para a criação em dança devem ser buscados mais nos sistemas de relações que ele ativa do que nas obras, propriamente ditas. Esse modo de compreendermos a criação em dança leva em conta não somente a criação de formas coreográficas que um corpo físico produz no espaço, mas, sobretudo, a materialização das relações que esse corpo (que não é somente físico, mas também energético, intelectual, emocional e espiritual) estabelece por meio da dança, com a dança e com aquilo que dança. Contudo, vale ressaltar que a dança, vista e elaborada através desse entendimento de corpo, tem como herança os pensamentos que também movimentaram e fundaram a Dança Moderna, por exemplo, na qual todo um modelo de conhecimento do corpo foi proposto; ou seja, "nem objeto físico nem corpo biológico, mas um corpo energético, feixes de forças" (Gil, op. cit., p. 122). É também por conta das "vastas reservas da herança moderna" que o intérprete de hoje pode "não inventar um corpo, mas procurar compreender, apurar e aprofundar o seu corpo e, sobretudo, fazer dele um projeto lúcido e singular" (Louppe, op. cit., p. 70). Ainda de acordo com Laurence Louppe (op. cit., p. 79):

A dança moderna já não era encarada como um campo de expressão homogêneo mas, pelo contrário, como uma visão heterogênea e profundamente individual que começava invariavelmente pela invenção de um corpo singular e irredutível, que Selma Jeanne Cohen expressaria cerca de trinta anos mais tarde através da máxima "a dança moderna é um ponto de vista", uma multiplicidade de pontos de vista, cada um propondo um pensamento corporal diferente.

Sendo assim, ao falar aqui em intérprete de dança, me refiro ao sujeito onde a dança - e a reflexão sobre o seu fazer - acontecem. Além disso, o uso deste termo não designa somente o sujeito que "executa uma dança", mas também aquele que constrói, inscreve, cria, (re)elabora, reflete, produz e que torna-se a própria dança. 
Ele também dá a ver todo um projeto de dança, a princípio existente enquanto imagem ou ideia; revela os fios invisíveis que tecem todo um projeto coreográfico, gerado e desenvolvido a partir dos processos criativos. Estabelece relações construtivas e criativas entre seus próprios desejos por expressar-se através de sua dança, com os desejos, pensamentos, propostas e procedimentos a ele apresentados por diretores-coreógrafos. Desse modo, podemos dizer que todas essas relações, bem como os modos como elas são estabelecidas, fomentadas e agenciadas em um processo criativo, também constituem o fazer artístico em dança, podendo ser denominadas como criações poéticas do sujeito-intérprete. Com isso, passamos a compreender aquilo que diz respeito à criação em dança a partir da investigação de especificidades inerentes à própria atuação do intérprete. Na maior parte dos estudos em dança, nota-se que essas especificidades quase sempre estão relacionadas ao próprio ato de dançar e de estar em cena. No entanto, nesse artigo gostaria de propor uma especificidade a mais: a possibilidade do intérprete poder atuar e também se desenvolver como o próprio sujeito da reflexão e da produção de conhecimento sobre seu fazer artístico. Nesse sentido, Nathalie Schulman (apud Kerkhove, 1997) nos adverte:

É legítimo dar aos bailarinos (intérpretes) uma identidade mais completa que seu simples corpo trabalhando para tornar visível o imaginário de outro. O bailarino porta o devir de uma coreografia na fugacidade de seu jogo. Ele o porta tanto mais esteja na base da concepção mesma da obra. E se ele está na origem deve, enquanto isso, batalhar sem cessar contra a perda iminente do sentido mesmo do seu ser. (Grifo nosso)

Dentro dessa perspectiva, portanto, o intérprete de dança traz em si, consequentemente, também as figuras do "intérprete-criador", do "criador-intérprete", do "bailarino", do "ator-dançarino", do "artista-pesquisador", entre outros. Pode ser entendido como o sujeito que participa ativa e poeticamente da construção e criação do seu próprio fazer e, fundamentalmente, dos saberes da dança. Com efeito, e para além, ao expressar-se no espaço-tempo efêmero de um movimento dançado, o intérprete tem a possibilidade de evidenciar e materializar, poética e criativamente, suas interpretações e visões de mundo, suas interações com o ambiente, suas relações com o outro, dentre tantos outros aspectos, oferecendo a si mesmo (mas também ao espectador), diferentes modos de reelaborarem-se enquanto sujeitos na dança, enquanto sujeitos-intérpretes de tudo aquilo que se lhes sucede; intérpretes de suas próprias experiências.

\section{Notas pedagógicas sobre o intérprete}

Para finalizar, gostaria de trazer para esse artigo alguns trechos de duas entrevistas realizadas com artistas-pedagogas da cidade de São Paulo ${ }^{6}$, a fim de contribuir com a reflexão de como tem se dado a prática pedagógica de artistas na formação de intérpretes atualmente. Na ocasião, as artistas-pedagogas foram convidadas a pensar acerca de: como têm se dado a formação dos intérpretes nos dias de hoje; como elas

6 As entrevistas foram realizadas durante o desenvolvimento da dissertação de mestrado do autor, defendida em 2016. 
têm analisado a presença de novos intérpretes na cena contemporânea, e; como vêm se constituindo seus entendimentos sobre contribuírem com a formação de novos intérpretes, mediante os seus contextos de atuação. Logo, apresentamos a seguir o que Angela Nolf e Lucienne Guedes ${ }^{7}$ disseram acerca dessas questões, expondo apontamentos e considerações significativas sobre o assunto. Vale ressaltar que ambas têm atuado e participado consideravelmente no campo artístico-pedagógico, colaborando com a criação artística de grupos e companhias, dando aulas em universidades e centros educacionais, orientando projetos e pesquisas em arte, dentre outras atividades.

Autor: Angela, baseando-se nas suas experiências pedagógicas, o que você acha que os intérpretes contemporâneos estão levando pra cena? O que você acha que a cena contemporânea está ganhando (ou perdendo) com esses novos intérpretes que estão chegando?

Angela Nolf: Eu não posso dizer que a cena esteja perdendo porque, às vezes, a gente tem que perder pra ganhar. Porque quando a gente troca ideia, você conversa, não é porque é o único caminho, a única maneira; ou eu acho que a técnica com que eu trabalho é... é uma maneira. Então, quando eu começo a ver, e eu procuro ver o máximo possível de dança, às vezes me incomoda um pouco, porque parece que tudo é possível. Tudo é possível, mas dentro de um respeito muito grande, de um pensamento muito grande, de uma qualidade muito grande. E também aí tem esses dois mundos. Porque, durante um período, a gente podia ver muito laboratório no palco, muito trabalho ainda em processo no palco. O que, na época, me incomodava. Agora, incomoda a mim. Outros podem achar extremamente interessante. Quando você vai ver um trabalho de improvisação, um trabalho que é costurado só através de trabalho de improvisação, é muita técnica, muito estudo pra fazer aquilo. E é extremamente interessante, acontece naquele momento. São pessoas extremamente disponíveis e capazes e trabalham muito pra fazer aquilo. Não vem da inspiração divina. Então, tudo é muito trabalho. Tudo é muito aprofundado. E têm maneiras de aprofundar. Uns acham que estão se aprofundando muito. Às vezes, o produto cênico não chega. Mas isso é uma questão... E não é muito de... são escolhas. São escolhas. Então, às vezes, a gente até arrisca num produto cênico que você não sabe muito bem no que vai dar. Porque você tem espaço pra arriscar; isso que é bacana. Você tem espaço pra arriscar e às vezes você erra. Erra, quando eu digo, quer dizer que você reconhece... Puxa! Não é esse o meu caminho. Mas, através de ter feito um trabalho de uma maneira e que, talvez, não tenha saído do jeito que você esperava - por causa dos intérpretes ou por $x$ motivos -, você dá um salto enorme para o próximo. Então, tudo é tão frágil. Tudo tem que ser tão generoso quando a gente olha. Eu fico muito preocupada porque, quando eu vejo alguém lá em cena, é muito difícil estar lá, né? Então eu respeito pra caramba. Seja a pessoa quem for. Seja uma antiga mestra minha ou os jovens. Mas, às vezes, eu acho que tem que ter muito cuidado pra estar lá. É outro lugar, tem que ter cuidado. E independe de tempo. Às vezes, a pessoa tem pouco tempo de estrada, mas

7 As artistas citadas autorizaram o uso de seus nomes verdadeiros na dissertação de mestrado e em artigos que incluíssem partes de suas entrevistas. Angela Nolf é bailarina e professora do Departamento de Artes Corporais da UNICAMP. Atua também como colaboradora de várias companhias e grupos de dança. Lucienne Guedes é atriz, dramaturga, diretora e professora de teatro. Também colabora com grupos e companhias de teatro. 
a pessoa é muito interessante. Não estou falando que só tem que ter profissional, que tem que ter estudado vinte mil anos pra poder estar lá. Não! Mas tem que ter alguma coisa séria pra dizer. Séria não de seriedade, mas uma verdade, uma responsabilidade lá dentro. E, em alguns momentos, ficou muito chato ver dança contemporânea. Muito chato! E eu não sei se eu que estou ficando muito chata e muito exigente; que também tenho que dar um passo pra trás e falar: Opa! O pessoal está fazendo. Eu não estou. Eu estou fazendo outras coisas; estou colaborando de outras maneiras. Ficou muito chato ver dança. Ou nós estamos muito exigentes também. E o que peca, o que eu acho um pouco, é essa produtividade pra esse supermercado de dança. Então, um projeto de seis meses, uma coreografia, mais outro prêmio, mais seis meses. Quer dizer, é um mundo de coisas pra se falar sobre esses fomentos e sobre os prêmios. Eles são extremamente importantes e foi muito bom pra dar uma alavancada; e alavancou e ajudou e ajuda, ainda, muita produção. Deu alicerce pra muita gente que tem o que falar; muita gente que tem uma assinatura pra desenvolver. E deu uma possibilidade pra isso acontecer. Mas foram se formando muitos núcleos que também estão se desenvolvendo. Mas, talvez, estão com um compromisso de produção muito em série. Tem que parar pra pensar. Tem que parar pra estudar. E como, talvez, eu tenha vivido outro tipo de cultura, a gente ficava fechado numa sala meses e meses estudando, porque não tinha uma hora e um fomento pra entregar. Hoje em dia é muito assim. Então, às vezes, têm grupos jovens que vão fazendo em série e não param pra estudar, pra repensar, amadurecer e maturar o que está se fazendo. E isso está perdendo um pouco qualitativamente. Até para as pessoas mais sólidas, que vão atrás de um formato pra sobreviver. E esse formato massacra. Eu acho que temos que achar outras maneiras de pensar a dança e pensar a sobrevivência com ela. Porque eu acho que nisso a gente está perdendo. Esse frisson de fazer dança. E, desculpa, eu não acho que... Eu dou aula há mais de... Falar quantos anos é terrível... mas eu dou aula há uns 40 anos. Você acredita que, às vezes, eu fico super insegura pra dar uma aula? Eu tenho que estudar mais porque, na minha aula, eu não alcancei o que eu queria. Ou não achei que os alunos... Eu devia ter feito mais, ou fui exagerada... Com 40 anos dando aula. E eu fico pensando: se a gente quando cria, quando dança... Às vezes vem em série, vem uma coisa, assim, muito...

Autor: Pré-fabricada?

Angela Nolf: Eu não vou falar que é pré-fabricada. É muito difícil. As pessoas estão seriamente envolvidas. Mas, às vezes, eu acho que tem que cavucar mais um pouco. E esse problema de ter que trabalhar em série as produções, muito próximas umas das outras, infelizmente não dá tempo para o artista se distanciar e estudar um pouco mais; pesquisar, negar o que está fazendo e ver outras coisas. Não dá pra acertar o tempo inteiro. Não dá! E eu acho que isso prejudica. E tem um grupo, por exemplo... Não existiam tantos grupos. Hoje em dia têm mais de 60, 70 grupos na cidade. Como que pode ter tanta gente criativa assim? 70 companhias de dança. E tem e é bacana. Mas, assim... É curioso: têm muitos grupos criando; têm muitos criadores-intérpretes - ou intérpretes-criadores -; ou eles saem já solistas porque o campo é pequeno, o dinheiro é curto. Então, "vou fazer meu solo"... Também é genuíno. $\mathrm{E}$ têm coisas incríveis, tem gente muito bacana. Em pouquíssimo tempo você vê artis- 
tas jovens trilhando um caminho e você fala: especial! Mas, não é um formato que cabe pra todo mundo. Então, se juntar pessoas, ficar um tempo maior com pessoas, estudando... Isso já está morrendo, não tem mais. As pessoas ficam com um grupo estudando, acaba o fomento e vão pra outro grupo e você não consegue viver aquela história, amadurecer um pouco mais, crescer artisticamente naquele pensamento daquele grupo, daquele criador. Algumas pessoas conseguem. Mas a maioria fica flutuando de um trabalho pro outro. Eu acho que isso perde um pouco também. Então, todos esses fatores prejudicam uma conjuntura que não dá pra traçar uma linha reta, que é por esse motivo. Mas, tem muita gente seguindo um caminho melhor.

Nesse momento, faço uma pausa na descrição da entrevista apenas para salientar que a artista Angela Nolf nos apresenta uma questão que há tempos também já intrigava Rudolf von Laban, a qual explicito aqui por meio das palavras de Eugenia Casini Ropa (op. cit., p. 24):

Somente afrontando e superando juntos, dia após dia, os problemas materiais e psicológicos do grupo, compartilhando privações e fadigas, assim como aspirações e satisfações, pensava Laban, é que o grupo poderia transformar-se em um "templo vibrante" de sua própria utopia expressiva, uma comunidade que soubesse se exprimir dançando, em uma espécie de oração vibrante, a quintessência da própria alma coletiva.

Autor: Angela, nesse sentido, você acha que as coreografias estão perdendo uma certa qualidade hoje em dia, em termos de... As coreografias estão ficando desinteressantes?

Angela Nolf: Se as coreografias estão ficando desinteressantes?

Autor: É. Eu não sei... parece que está se desenvolvendo, hoje em dia, um preconceito muito grande com "coreografia". O que você acha?

Angela Nolf: Eu acho que são outras formas de trabalhar. Por exemplo, de onde eu vim, você lia a coreografia no papel. A coreografia estava escrita em Benesh ou Labanotation. Eu tinha que aprender a ler. No Royal Ballet a gente tinha que aprender a ler aquilo. E, daí, chegava uma pessoa pra passar pra mim aquilo lá. Eram coreografias estabelecidas; com algumas revisões, às vezes, até adaptações para o meu corpo. Mas eu tinha que seguir aquele formato coreográfico. Trabalhei aqui também com pessoas que coreografavam e que coreografam até hoje. O Luís, a Ana, a Suzana. Várias pessoas que estão fazendo outras coisas, mas que trabalham com escritas coreográficas. A Vanessa trabalha com escrita coreográfica... O próprio Borelli trabalha com escrita coreográfica, também. Mas, daí, ele vai moldando pra dar a atmosfera daquela cena. Mas é tudo delineado coreograficamente. Já alguns intérpretes ou alguns criadores trabalham dentro de uma improvisação, dentro de um lado sensorial, dentro de uma evolução de corpo que vai pra outro caminho, que pode ser fantástico. Mas tem que ser muito maduro, tem que ter muita estrada. Eu não digo em idade, mas compreensão daquilo; um corpo muito disponível e inteligente pra caminhar naquele discurso que o coreógrafo quer e que o criador quer. E pode ser muito interessante. Quer dizer, têm várias maneiras. Porque, quando a gente fala... Existe muita 
resistência, sim, dos bailarinos. Porque quando você dá uma... Até os estudantes... você dá uma sequência e eles dizem: "Ah! Eu vou ficar aprendendo passinho?" Não são passinhos. Mas o que você pode fazer desta sequência no seu corpo. Eu estou dizendo... Até as sequências desconstruídas. "Ah! Mas eu quero... Eu sou um improvisador." Ele não consegue nem reter. O olho dele não consegue nem enxergar o movimento, porque ele só sabe fazer o movimento que o corpo dele está habituado a fazer enquanto criador-intérprete, pra ele ou para o núcleo que ele trabalha. Aí, quando chega um coreógrafo ou criador que vai formalizar uma construção coreográfica, tem uma enorme dificuldade de pegar, porque nunca treinou pegar alguma coisa, que também é um jeito de dançar. É um jeito. Você pode até treinar algumas... Formalmente, uma coreografia muito fechada, uma proposta fechada. Você treina muito aquilo e o coreógrafo começa a quebrar, começa a jogar fora um monte de coisa. Mas o resultado partiu de outro lugar. Os bailarinos hoje, em grande maioria, eles improvisam e vão através da sua facilidade em improvisar. Que é um caminho muito legal, também. Que eu, enquanto intérprete, senti muita falta, aliás. Porque, como eu vim de um treino muito "assim" (faz gesto com as mãos, indicando a viseira utilizada nos cavalos), quando me davam uma disponibilidade, eu não sabia pra onde ir. É péssimo! Então, os dois mundos... Seria muito interessante se eles fizessem isso (faz gesto unindo as mãos), e não ficassem só aqui ou só ali. Hoje eu acho que eu tenho um pouquinho mais de disponibilidade; se as pessoas me dão algumas informações eu consigo apresentar no meu corpo um pouco.

Autor: Das duas coisas?

Angela Nolf: Na improvisação é muito difícil. Porque vinha pra outro código, que também é um código. Algumas companhias ainda trabalham com esses códigos fortemente. Até muitos contemporâneos trabalham com códigos muito fortes. E até a dança contemporânea está repleta de códigos. Então, quando a gente vê... Você me perguntou se as coreografias não estão interessantes: eu acho que é o assunto. Não é tanto a coreografia. Porque hoje não se olha a coreografia... Eu não olho a coreografia assim (faz gesto com as mãos, indicando um plano horizontal). Tem um colega que me manda uns vídeos de coreografias bem assim (faz o mesmo gesto anterior). Lindos os bailarinos. Ele cria e tal e me manda. Eu tenho uma dificuldade enorme de fazer uma... Eu aprecio... mas de fazer uma apreciação pra ele, porque já não me satisfaz. Como ele entende ou como ele aprecia a simetria, as pessoas. Ele ainda... Eu não falo ainda porque ele vive aquilo. Eu procuro viver outras coisas. Então, eu acho muito difícil. Eu quero me encantar com outras coisas. Eu respeito. Quando são coisas bem feitas, eu digo: Pô! Mandaram bem. Mas eu já fiz bastante disso e eu acho que eu quero me encantar com outras coisas. Sem negar. E eu acho que essa juventude de hoje em dia está aprendendo a não negar, o que eu acho bacana. Agora, eu não acho que estão pouco criativos. Tem bailarino... eu acho que falta corpo. Falta corpo para as coreografias ficarem interessantes. Porque tem muito de um montão de coisa. Muito adereço, muito externo, mas não tem corpo. Falta corpo. E corpo não é pirueta, não é girar, não é... É outra questão. Mas, pra ter corpo, precisa ficar muito tempo trabalhando uma informação; que o seu corpo construa alguma coisa. Falta essa construção de corpo, eu sinto. Fica um corpo que também é muito bacana, mas 
é aquele corpo... Um corpo blasé, um corpo fácil. E se fazer fácil em cena é muito difícil. É outro lugar que eu estou falando. Talvez, fica um pouquinho... Eu estou colocando como uma disponibilidade corporal que às vezes não tem, um corpo disponível, fácil, cotidiano que não é bom. Pode ser muito bom...

Autor: Sim, mas se o intérprete souber trabalhar cenicamente isso, né?

Angela Nolf: É... e com uma maturidade com o corpo. Aí, você vai... Você vê que tem outra história atrás, aqui (indica a cabeça), que carrega esse corpo. Ele pode estar parado, ele pode estar sentado. Dança é isso tudo... Estar andando. Não estou falando do corpo que gira e faz. Mas falta corpo. Falta um corpo que pensa mais. E isso eu sinto falta. Aí eu falo: as coreografias estão fracas? Não, imagina. Tem gente muito legal. Falar a palavra coreografia, hoje em dia, parece que é o formato coreográfico. Você vê alguns criadores, talvez de uma escola mais antiga, que são muito interessantes e ricos pra gente aprender com eles, com a escola antiga. Quando eu falo... É uma outra visão; a gente aprende muito com essas pessoas. E, às vezes, muitos pularam essa etapa, de talvez viver algumas coisas no corpo, não só na cabeça, mas no corpo. E aí, você vivendo, você pode ter escolhas, ter mais escolhas. Têm algumas pessoas que, quando você assiste a coreografia... Quando eu falo coreografia é porque eles trabalham coreograficamente. O Luís Arrieta, ele fez uma montagem pro Balé da Cidade (de São Paulo). Eu conheço um pouco a sistemática, a maneira como ele pensa... É muito curioso. Você assistiu o duo dele com a Irupé? Não assistiu? É lindo ver. E eu entendo um pouquinho... Dois intérpretes mágicos. Mas os mundos muito diferentes, o dele e o dela. Isso é rico! De onde ele vem, como ele se estrutura, como ele pensa hoje com o tempo dele, com o corpo dele. É maduro, né? É inteligente. Assim como ela; de onde ela vem. Então, quando eu vejo um coreógrafo assim, que eu já até trabalhei um pouco, junto, eu entendo a estrutura como ele cria. Quando eu vejo alguns trabalhos... Eu vejo o Kylián ${ }^{8}$, eu vejo o Forsythe ${ }^{9}$... A gente já tá um pouco acostumada a entender até algumas repetições de procura estética. Embora eles sejam... têm feito coisas incríveis e trabalham com uma formalidade coreográfica muito grande. Então, coreografia não quer dizer corpo criativo que gira e faz... É como você lida com isso. Como que esse corpo inteiro lida com isso. Eu acho que é sobre isso que é interessante pensarmos.

Ao final das palavras de Angela Nolf, vale lembrar que a questão inicial que despertou suas reflexões, descritas acima, estava relacionada à interferência dos intérpretes sobre a cena contemporânea. Já para Lucienne Guedes, a perspectiva de entendimento acerca dessa questão foi invertida, de modo que a pergunta foi sobre os desafios apresentados ao intérprete frente à cena contemporânea. Sigamos, então, com as reflexões e apontamentos feitos por Lucienne acerca dessa questão artístico-pedagógica, levando em conta que a artista se colocou diante da pergunta tanto como pedagoga quanto, também, como intérprete.

8 Jirí Kylián (1947), bailarino e coreógrafo checo, de Praga.

9 William Forsythe (1949), bailarino e coreógrafo estadounidense. 
Autor: Lucienne, considerando a sua trajetória como artista-pedagoga, qual o maior desafio que você acha que vem sendo apresentado aos intérpretes pela cena contemporânea?

Lucienne Guedes: Olha... eu tenho muito medo de ficar... pra trás... de não perceber essa cena a que você se refere. Eu estou tentando ao máximo... eu quero sempre estar... muito viva nesse sentido... mudando paradigmas... eu quero muito, assim. Então, eu espero... portanto, eu só posso avaliar isso sob o meu ponto de vista... reconhecendo que ele quer se mover, muitas vezes. Mas se a gente for falar de teatro contemporâneo, que eu acho que é o que a gente tem que fazer; e pelo que eu tenho encontrado em salas de aula, a questão principal talvez seja: o que é que você quer, hein? Afinal de contas, o que é que você quer com esse teatro que você quer fazer? Ou o que é que você quer que o seu teatro faça, afinal de contas? O que é que move você a estar nesse lugar? Então, eu acho que a principal coisa na qual eu investiria hoje, como pedagoga, a principal coisa seria fazer essa pergunta... e eu acho que ela tem, principalmente, dois flancos que são a preparação intelectual, que está muito difícil, e as condições de entender isso fisicamente, completamente, assim. Como é que você pode se dispor pra isso? Porque não adianta você só ficar pensando intelectualmente como é que você se vira com os problemas que a gente tem. Então... talvez possa haver até uma outra perna nesse tripé, que eu ainda não descobri... mas eu acho que tem que ter, sim, uma formação intelectual aberta, que olha para as coisas de uma maneira relacional, porque teatro é relacional, precisa ser relacional... precisa fazer essa tal dessa experiência funcionar; e a outra é o que eu preciso ter pra conseguir fazer essa experiência acontecer. E eu acho que aí é corpo e tudo junto, sem separar... mas é, sobretudo, de expor isso. A Eleonora Fabião ${ }^{10}$ tem uma ideia muito interessante desse performer, digamos... ela acredita que é um tripé, que é a capacidade de se conectar, ou seja, de conectividade, a memória... que vem através das posturas e... e a capacidade sensível... a sensibilidade. Ou seja, a capacidade de se conectar com os outros, seja parceiro de cena ou com o outro que está ali, e isso é inclusive energético, é uma capacidade que a gente pode se dispor, a gente pode garantir que a coisa esteja, mais ou menos, disposta; essa coisa da memória, que você busca pelas posturas ou pelo corpo-testemunha, que aí já sou eu falando... que é o que você aciona como memória de si e do outro; e essa ideia de ativar a sensibilidade, o tato, o olhar e tudo... de ser uma pessoa capaz de ativar a sua própria sensibilidade... os sentidos, mesmo, numa potência alta. Então, se a gente pensa... vamos pensar nesse corpo relacional e na capacidade intelectual que ele tem de articular os materiais. Eu digo essa capacidade intelectual... pode parecer um treco chato, mas eu digo de um mundo que, pelo menos aos meus olhos, ele se apresenta como um... de uma maneira que a gente não pode ser ingênuo; nesse sentido eu estou falando... de você não ser ingênuo diante do que está acontecendo. Não fique achando que... não... não dá; pra ser ingênuo não dá! Você pode ser o que você quiser; você pode ser suave, delicado... se você quer. Mas o que não dá é pra ser ingênuo e achar que

10 Eleonora Fabião (Rio de Janeiro/RJ) é professora adjunta e coordenadora do Curso de Direção Teatral da Escola de Comunicação da Universidade Federal do Rio de Janeiro. Trabalha principalmente com os seguintes temas: arte da performance, estudos da performance, direção teatral, arte do ator, dramaturgias do corpo e dramaturgia experimental contemporânea. (Informações obtidas por meio do seguinte endereço eletrônico: http://teatropedia.com/wiki/Eleonora_Fabião). 
a coisa está acontecendo quando não está, ou achar que você simplesmente pode fazer o que você quiser sem pagar o preço daquilo que está sendo feito, sabe? E quando eu faço esse tipo de questão ou quando eu proponho esse tipo de discussão... intelectualmente não sejamos ingênuos; pensamos na forma relacional e qual é esse corpo relacional... e eu pergunto o que você quer que seu teatro faça? Eu recebo muito brilho no olho, assim. É pouca gente que não quer discutir isso... e é bom. Mas eu acho que a principal coisa é a gente descobrir como essas coisas vêm juntas como experiência. Eu não sei como é que faz isso, né... mas, pelo menos pelos lugares ou pelos coletivos que eu já passei, essa pergunta é importante e sempre foi importante, desde o Vertigem de 1992 até o Vertigem de agora, do ano passado, também o Teatro de Narradores... a própria Cia Livre e a Balagan. Quanto mais clareza as pessoas têm daquilo que elas querem que o teatro faça, mais importante vai ser a busca de conseguir um encontro que revele isso. Agora, isso não é fácil, mas isso me dá cada vez mais vontade de ficar fazendo essa pergunta nos ambientes pedagógicos, assim... porque as respostas que chegam me tiram do lugar.

Com as palavras de Lucienne Guedes, encerro, portanto, a descrição dos trechos das entrevistas que gostaria de compartilhar, destacando algumas questões que, nesse momento, se fazem necessárias: como podemos evidenciar os modos de pensar, refletir e perceber as experiências vividas pelos intérpretes de nosso tempo? Como suas reflexões podem nos fornecer aspectos de suas distintas atuações no campo da dança? Como as narrativas e discursos de intérpretes de dança podem nos revelar os processos de transformação pelos quais a dança (e as artes do espetáculo) vêm passando na contemporaneidade? Como o intérprete também pode garantir à dança novos modos de investigar suas escritas e (re)elaborar suas escrituras? Para tais questionamentos, reconheço que não há respostas que não gerem, possivelmente, outras e novas indagações. Nesse sentido, é importante que, cada vez mais e ininterruptamente, sejam reinventados e propostos novos (e outros) modos de realizarmos a escrita da dança. De acordo com Laurence Louppe (op. cit., p. 49):

Esta falta de hierarquização de suportes testemunha igualmente os poucos lugares onde o corpo dançante pode inscrever a marca do seu pensamento. É deste modo que se elabora o fazer da dança - através de mil ressonâncias dispersas que um projeto difuso pode captar aqui e ali, sem limite nem lei, como tantos aglomerados de consciências e de imaginários.

Contudo, gostaria de esclarecer um ponto importante: falar sobre o intérprete é diferente de ser intérprete; falar sobre a cena é diferente de estar em cena, assim como falar sobre dança é diferente de dançar. No entanto, a tentativa aqui foi a de contribuir com os modos possíveis de traduzirmos em palavras este ser/estar intérprete de dança, com vistas à produção do conhecimento nessa linguagem artística. Portanto, finalizo dizendo que a escrita materializada nesse artigo partiu de um corpo atravessado por experiências vividas com a dança e com o movimento: um movimento que também se realiza em direção à escrita. 


\section{Referências}

BAUMGÄRTEL, Stephan. Subjetividades na cena contemporânea: expor a encenação citacional e suas lacunas. S. J. Rio Preto, SP: Catálogo do Festival Internacional de Teatro, 2009.

BOURCIER, Paul. História da Dança no Ocidente. São Paulo: Martins Fontes, 1987.

GIL, José. O movimento total: o corpo e a dança. São Paulo: Iluminuras, 2013.

KERKHOVE, Marianne Van; PICKELS, Antoine; et al. Dossiê: Dança e Dramaturgia. Trad. Cássia Navas. Bruxelas: Contredanse, 1997.

LOUPPE, Laurence. Poética da Dança Contemporânea. Lisboa: Orfeu Negro, 2012.

PAIXÃO, Paulo. Coreografia: gramática da dança. Site: idança.net, 2003. Disponível em: http://idanca.net/coreografia-gramatica-da-danca/. Acesso em: 16 jun. 2019.

PEREIRA, Sayonara. Rastros do Tanztheater no Processo Criativo de ES-BOÇO: Espetáculo cênico com alunos do Instituto de Artes da UNICAMP. São Paulo: Annablume, 2010.

QUILICl, Cassiano S. Antonin Artaud: teatro e ritual. São Paulo: Annablume; Fapesp, 2004.

RANCIĖRE, Jacques. O inconsciente estético. São Paulo: Editora 34, 2009.

ROMANO, Lúcia R. V. Por uma teoria da atuação. 2013. Disponível em: http://www. revistas.usp.br/pesquisator/article/view/52350. Acesso em: 16 jun. 2019.

ROPA, Eugênia C. A dança e o agit-prop: os teatros não teatrais na cultura alemã do início do século XX. São Paulo: Perspectiva, 2014.

Recebido em: 17/06/2019 Aprovado em: 05/08/2019 